\title{
Deconstructing Social Unrest as A Response to Redefine Strained Relationships between Students and University Authorities
}

\author{
Bunmi Isaiah Omodan ${ }^{1}$ \\ ${ }^{1}$ School of Education Studies, Faculty of Education, University of the Free State, South Africa \\ Correspondence: Dr Bunmi Isaiah Omodan, School of Education Studies, Faculty of Education, University of the \\ Free State, South Africa.
}

Received: July 17, 2020

Accepted: September 11, 2020

Online Published: September 18, 2020

doi:10.5430/ijhe.v9n6p178

URL: https://doi.org/10.5430/ijhe.v9n6p178

\begin{abstract}
The university system in Nigeria has been characterised by persistent social unrest traceable to strained relationships between students and the university authorities. Observations, reports and literature confirm that students' unrest in the universities has become a clog in the wheel of development and speedy actualisation of university goals and objectives. The need to manage and maintain the social space for relative peace and tranquillity thereof is expedient. This study aims at redefining students and university authority relationships as a tool to deconstructing students' unrest in Nigerian universities. Human Relations Theory of Management (HRTM) was used to theorise this study while Transformative Paradigm (TP), which was adopted as a stance to forestall existing and future unrest was used to lens the study. Participatory Action Research (PAR) was adopted as a research design for the study. The sample size for this study consists of 10 participants: three student leaders, three university management members, two lecturers and two security personnel were selected using expert sampling techniques. Focused Group Discussion (FGD) was used to collect data from the participants, and the data collected were analysed using Socio-thematic Analysis (StA). This study reveals that inadequate funding is a significant challenge resulting in students' unrest. Contrarily, the provision of student personnel services along with modern maintenance culture, transparency and accountability were found to be the dimension of peaceful university operation devoid of social unrest and therefore becomes a tool to deconstruct the strained relationship between students and the university authorities.
\end{abstract}

Keywords: students' unrest, crisis management, university authorities, students-management relationships

\section{Introduction}

The student community in Nigeria is known globally for solving its problems and social issues through agitation, protest cum violence. This seems to have been inherited by the millennial of the new Nigeria from the shackles or leftovers of colonialism and subsequent military dictatorship in the past. Reports in the university system, over the years, confirm that there had been pockets of unrest, protests, and social wars among the students' populace: between students and the university authorities, students and security agencies such as Nigeria Police and other armed forces (Onwurah, 2000; Ekundayo \& Alonge, 2010). Consequently, this has threatened, severally, productivity and social development, not only in the university community but societal development, general peace and tranquillity of the society (Etadon, 2013; Davies, Ekwere \& Uyanga, 2015).

The menace of students' unrest in Nigerian universities can be traced to the perpetual maladministration of universities in which, according to Adeyemi (2009), has its consequences. Among these consequences manifested is the continuous unrest on campuses by students as a result of perceived threats from management's lack of adequate provision of welfare, social and educational facilities, among others. According to Falua (2004), these unrests have led to wanton destruction of the academic calendar and social inconsistencies. Some of the most striking unrest include the 1971 crises at the University of Ibadan; 1978 agitation at the University of Lagos which extended to other universities; 1992 crises at the University of Ibadan; 1999 students' crises at the University of Ado-Ekiti, and 2001 crises at Federal University of Technology, Akure (Akinyemi, 2002).

The 2002 Lagos State University crisis was over the brutal murder of a union leader and the Ebonyi State University crisis which took place in 2004 was as a result of the bad road leading to Ishieke campus. In 2016, the University of Lagos witnessed students' protest and agitation due to an e increase in school fees. The University of Ibadan also went on protest and agitate for a reduction in their school fees in 2017 , which also led to the closure of all academic 
activities by the vice-chancellor of the university. Ladoke Akintola University also witnessed students' unrest in recent times as a result of inadequate funding which led to the indefinite closure of the university (Omisade, 2017; Premium Times, 2017). Many of these crises have been linked to university inability to provide social and educational amenities to aid students' welfare and academic development (Etadon, 2013).

At the scenes of the various protests made by student movements against the university system in Nigeria, constant allegations have been made by student leaders and even the staff unions that universities and their management lack functional communication strategies and dialogical principles to ensure that students' voices are heard (Adeyemi, 2009; Nwankwo, 2014; 2016). Given this, Bentley (2012) confirms that communication, relationships and principles of negotiation to maintain relationships in universities had been committed into the circumstantial constraints of power politics (Bentley, 2012). Moreover, external and political interference, along with underfunding of university education are also major challenges that are making the university community ungovernable, more especially in the faces of political interferences and unavailability of educational material to pursue the goals of university education (Etadon, 2013; Arikewuyo, 2015; Ogunlade, Ekundayo \& Omodan, 2016; Ahmad, Farley \& Naidoo, 2018). As a result of these social and internal conflicts, both university and government infrastructure are destroyed, and funds are wasted, which further compounds the problem of inadequate resources and leads to inadequate provision for the social development of the universities and the country at large. In some cases, students' unrest has led to the death of students, staff and many other persons in the process (Aluede, Jimoh, Agwinede \& Omoregie, 2005; Oludayo, Uche, Oludayo $\&$ Eche, 2014). Similarly, the government has not succeeded in trying to redress the economic imbalances of the past, which has resulted in university inability to fulfil its aims and objectives alongside its responsibilities to students.

In response to students'-oriented unrest/crisis which has continued to pose a challenge to university productivity and relative peace, Sri Lanka developed a university autonomy and adequate funding policy. This emanated from intensive research conducted by the National Education Commission (NEC) on the apparent socio-political effect and "Impact of Student Violence and Indiscipline in Universities and all Tertiary Education Institutions in Sri Lanka" (National Education Commission, 2007). This solution, according to Weeramunda (2008), provided a policy option that enhanced the peaceful existence of stakeholders in higher institutions in the country. In response to the crisis that erupted from students and civil societies due to the unavailability of tertiary institutions, including universities to accommodate all the secondary school graduates in 2016, the Government of Papua New Guinea introduced collaborative governance (Government of Papua New Guinea, 2017). This approach addressed the demands of students' unrest and proper management of higher education by formulating and implementing a collaborative governance policy which resulted in the increment of physical and academic resources catering to all prospective university students in the country (Eldridgea, Larryb, Bairdc \& Kavanamur, 2018). However, existing literature has not revealed whether the Nigerian government have put any policy in place on how to manage and/or respond to students' unrest in her universities.

Complementing the solution provided by the Government of Papua New Guinea, existing literature further reveals that the provision of student personnel services such as quality health services, physical infrastructure, welfare materials and equipment, and library facilities are the amenities needed to make students comfortable in the university community (Akpan, 2016). In my argument, these are not enough until there are accountability and transparency to motivate stakeholders to develop trust in their leaders and university management. When accountability and transparency are adequately present, these will enhance peaceful coexistence between the students and university authorities (Aluko, 2011). This is confirmed by the conclusion of FrøLich (2010), Fox (2015), and Omodan, Dube and Tsotetsi (2018), that the implementation of facilitative leadership style and establishment of accountability and transparency will also enhance easy management of stakeholders in the university community. Based on the above, evidence shows that there is a strained relationship among the critical stakeholders in the university system not only in Nigeria but in the global space. However, the focus of this study, therefore, remains to fashion out a way forward by enhancing the management of students' unrest in the university system. By so doing, the challenges facing the management of students' unrest will be explored and pave the way for the provision of possible solutions to the menace.

\subsection{Theoretical Framework: Human Relations Theory of Management}

This study is based on the Human Relations Theory of Management (HRTM). The development of this theory began in the early 1920s during the Industrial Revolution (Mayo, 1933). Elton Mayo developed it during a stage of productivity being the centre focus of business (Barnard, 1938). The hypothesis explains s that representatives want to be associated with a group that encourages the advancement and development of an association (Mayo, 1933). It likewise assumed that when directors and different specialists relate commonly with their subordinates, during which 
the subordinates' or workers' mental wants are remembered, it will impel excellent "human relations in the organisation" (Stoner \& Wandel, 1988). That is why Oraemes (1997:64) stressed that the humane treatment of subordinates builds endeavours to democratise the system. Undie (2001) believes that school directors need to consistently start steps to fulfil both the persuasive and mental needs of hierarchical partners to guarantee better efficiency. The ramifications of this theory, as confirmed by Odionye (2014), is that the more incessant the connection between any two gatherings, the more prominent the propensity of co-activity between them. This most prominent assumption guiding the focus of this study, among many others, is motivation by social, psychological and economic incentives.

This was recommended by the report of Hawthorne study that social and psychological needs alongside economic incentives motivate employees for better productivity (Mayo, 1933). This is to support the argument that human relations, according to this theory, is concerned with people's needs, satisfaction and strategies to accommodate those needs for better productivity. To buttress this point, Wziątek-Staśko (2015) concludes that when subordinates are not recognised and appreciated with economic incentives which bother on adequate remuneration and funding, this will reduce the effectiveness and efficiency of subordinates and thereby affect their feelings towards productivity. This is to say that less financial capability in organisations, most especially universities, will continue to generate ill feelings and disagreements. This aligns with Smith and Rupp (2003) views that performance is the result of individual motivation and resistance to change. Luthans and Stajkovic (1999) also support this notion by reiterating that the advancement of rewards, monetary incentives, and organisational behaviour to a large extent, contribute to individual behaviour in an organisation. This is because motivation influences even managements' effectiveness (Analoui, 2007).

Along these lines, this theory is unequivocally applicable to this research. It is so because it represents the significance of comprehensiveness of partnerships, financial incentives and motivation as a panacea to the smooth running of the university system and its tasks. It also clarifies why university management ought to perceive different popularity-based devices to impact co-activity and connections. When students, including concerned members of staff, are recognised and their concerns over students' welfare acknowledged, an improvement in the university framework will be perceived. This process of conflict management and resolution will inspire the conduct of future protesters who will in the same vein, act responsibly. This will, in turn, guarantee the quiet resolution of impending crises and agitations.

\subsection{Research Question}

Based on the above problems, the following research question was formulated to guide the study:

- How can students-university authority relationships be solidified to respond to students' unrest in Nigerian universities?

\subsection{Research Objectives}

To answer the research question, the following objectives were raised to guide the study:

- To examine the challenge associated with the management of students' unrest in Nigerian universities.

- To explore possible solutions to the challenge of managing students' unrest in Nigerian universities

\section{Methodology}

\subsection{Paradigm and Research Design}

This study is approached from the qualitative perspective; qualitative approach to research involves the understanding of opinion, motivation and the world of reason (Mertens, 2012). The study is also situated in the transformative paradigm. This paradigm is appropriate for this study based on the research philosophy, approach and the choice of research design which is participatory action research (PAR). Transformative paradigm, according to Mertens (2005) and Dube (2016), also falls within the purview of participatory action researchers, with a focus on the dynamics of emancipation. In the methodological assumption of transformative paradigm, the purpose of the research is to destroy the myth, illusions, and false knowledge, and empower people to act and transform their society indigenously (Chilisa \& Kawulich, 2012). This assumption was a deviation from positivist ways of researching to promote participants' recognition in the process of addressing human and social issues.

Participatory action research (PAR) was adopted to design this study, PAR as a participatory way of conducting research appears to be democratic considering its characteristics that pay essential attention to the equality and power differences between or among the researched community (Dube, 2016). These democratic tendencies according to Zuber-Skerritt (2015) and Wood and McAteer (2017) encourage full involvement of the community in the process of Published by Sciedu Press 
creating knowledge to sustain empowerment of the less privileged and undervalued people of the community. Hence, this study argues that trusting the unanimous partnership between the researchers and the researched (the community) to create knowledge and action is democracy. This is also corroborated by the conclusion of Watter, Momau and Restall (2010) that PAR is a research method that equitably carries along with the participants from the planning stage to the results' communication stage. The action part of PAR was implemented by ensuring that the researchers are involved from the planning, process and solution stage. This enables the researcher and the participant to jointly provide a solution to change the social status quo of unabated students unrest in Nigerian universities.

\subsection{Participants and Selection of Participants}

The sample size for this study consists of 10 participants. These participants are three students' leaders; one past student leader and two current serving student leaders, three university management/authority members were selected, two lecturers and two security personnel were equally selected using expert sampling techniques. This technique is appropriate because the participants' assessment with the degree of knowledge about the culture of the study is purposely essential (Kitamaya \& Cohen, 2010). In this sampling method, known or assumed experts in the study area are grouped to share their definite knowledge and experience about the problem directly from individual or group of respondents (Etikan \& Bala, 2017). This sampling technique, according to Gifford (2015), ensures a better way to construct the experts' views in particular actions and happenings.

\subsection{Method of Data Collection}

Focus group discussion (FGD) as a qualitative method of data generation which usually comprises people with similar experience, characteristics and background, whose focus is to find solutions to issues through talking (Dilshad \& Latif, 2013) was adopted to generate appropriate data. This was implemented by organising three meetings with the participants within the interval of one week. The first meeting introduced the project to the participants. They were enlightened about the background, the problem, the purpose, the theoretical frameworks, research questions, objectives, the methodology and the rudiment of the research design was adequately explained and taught them. The second meeting started with a unanimous selection of a moderator among us. The moderator was in charge and controlled the time allocated to each participant on each discussion and he was also responsible to ensure decorum in the process of the discussion. The discussion started by discussing the constructs as highlighted in the objectives of the study. This third stage was basically to consolidate on the entire process of the research from the preliminary stage to data generation stage and above all, it is a stage where the study was finalised through the unanimous deliberation by the researcher alongside the co-researchers who were also the participants. In this stage, the analysed data and the findings were reconfirmed.

\subsection{Data Analysis}

The study adopted socio-thematic analysis (StA) to make sense of the generated data. StA was first used by Bunmi Isaiah Omodan in a project done in University of the Free State between the years 2018 and 2019. Socio-thematic analysis, according to Omodan (2019), is a simultaneous implementation of Braun and Clarke's six steps of thematic analysis, which borders on breaking down of the transcribed data into themes, and conversational analyses which borders on how the sociality among the participants could be tested to understand how they live or do things together (Braun and Clarke, 2006; Nordquist, 2019). This method of data analysis was adopted because it enables the researcher to categorise the data into themes according to the objectives of the study and subject the data into sociality test to fulfil the conversationality involved (Omodan, 2020). This method helped the researcher to socially interpret and understand the social dependencies and/or independence and the social interactions coming from the social differences of the participants.

\subsection{Ethical Consideration}

To get to the researched, a research assistant was employed in the selected university in Nigeria to fast track the data generation process. This enabled the researcher to quickly reach out to the participants and garner their maximum cooperation (Fakunle, 2016). To protect the participants and their identities during the process of generating data from potential harm which is one of the importance of research ethics (Dube, 2016), their liberty to withdraw from the survey at any point in time was communicated and guaranteed to prevent any inconvenience. This research was approved by the ethics committee of the University of the Free State with approval Number: UFS-HSD2018/1105. To further ensure and protect the identity of the participants, they were represented with pseudonyms in the data presented below; Student Leaders (SL1, SL2 \& SL3), University Authority (UA1, UA2, \& UA3), University Lecturers (UL1 \& UL2), and Security Personnel (SP1 \& SP2). 


\section{Data Presentation and Analysis}

The data were presented following the objectives of the study; this was done by firstly dealing with the challenge facing the management of students unrest in the university system and also the possible solutions that are capable of nipping the problem into the abyss of oblivion. The major challenge was inadequate funding while the suggestible solutions were the provision of student personnel services, accountability and transparency. The table below further shows the thematic representation of the analysis.

Table 1. Thematic representation of data based on the research objectives

\begin{tabular}{ll}
\hline Objectives & Analysis of Sub-themes \\
\hline $\begin{array}{l}\text { 1. } \\
\text { The challenges associated with the } \\
\text { management of students unrest in Nigeria } \\
\text { universities. }\end{array}$ & 1. Inadequate Funding. \\
2. $\begin{array}{l}\text { Suggestible solutions to the challenges of } \\
\text { managing students unrest in Nigeria } \\
\text { universities. }\end{array}$ & $\begin{array}{l}\text { 1. Provision of Student Personnel Services. } \\
\text { 2. Accountability and Transparency. }\end{array}$
\end{tabular}

\subsection{The Challenges Associated with the Management of Students Unrest in Nigeria Universities}

\subsubsection{Inadequate Funding}

University education in Nigeria, according to various observations and literature, is battling with the barriers of inadequate funding. This is not limited to underfunding alone, but poor financing, mismanagement and corruption also contribute to financial challenges in the system (Farley, A. \& Naidoo, 2018). This challenge may be linked to the increasingly high cost of Education in Nigeria (Famade, Omiyale \& Adebola, 2015). Also, the inability of the Nigerian education system to implement UNESCO recommendation that at least $25 \%$ of the annual budget of any given country should be allotted to education could be one of the major factors responsible for the inadequate funding in the university system. From various comparative studies, it revealed that Nigeria is still one of the countries that allocated less than $10 \%$ of its annual budget to education (UNESCO, 2002, 2010; Afe, 2014; Premium Times, 2017). To confirm this, various statements made by participants in the course of our group discussion revealed that all the participants unanimously agreed that the funding of education in Nigeria is a big challenge. This is shown in the following conversations:

UA2: "There is a population explosion to the extent that inflation has also taken over. As a result, it is no longer feasible for the government to fund the costs of education. Therefore, the inability of the government to provide free education will always be an obstacle to management because there are not enough funds in place to manage the educational institution."

UL1: "In this university, the government subvention from the government is approximately 260 million naira; meanwhile, the waybill of the university is way above that. As a result, the university management and the government decided to levy the students unfairly (way too high), which led to a protest."

SL1: "The management of the university came to that decision of levying students because there are no adequate funds and enough financial assistance from the government to fund the university and the university must survive."

SL3: "It is a fact that the government or country has enough resources to do that, but the reality is, the government is not performing its duty when it comes to education."

The first statement referred to university explosion and inflation, meaning that the funding usually allocated to universities may not be adequate to take care of the financial needs of the university based on the increasing population of students seeking admission into universities. This, according to the participants, has made it practically impossible for the government to implement the "free education for all" policy. This lack of space also contributes to whether or not the university will be manageable by the university authorities. This may be because of people's management and management need finance to be sustained. The second and the third statements confirm that even the statutory allocation of these universities from the government are not enough to cater for the recurrent expenditure, let alone capital expenditure. This, on many occasions, resulted in an unfair levy against students, which makes disagreements inevitable. Socially speaking, this act of management will appear to students as extortion, more especially when what they get is not commiserating with what they pay. The fourth statement seems to assert that 
there is money, but the government is proving unresponsive to the plight of education in Nigeria. This confirms Afe (2014) and Ahmed et al. (2018) analyses that the Nigerian government is not living up to the average in terms of proper funding for her education system. This is a propeller of crisis in the system, and the reason is evidenced in the conversation below.

\section{UL2: "The problem in Nigeria is that the government has ceased to be responsible for education and other educational activities. The students' hostels around Nigeria are of inferior standards, and they are in appalling conditions. Taking a cue from the frustration-aggression theory, when one becomes frustrated, they eventually become aggressive. When it gets to an aggressive point, one will go back to tackle and confront the cause of his/her frustration."}

This statement dwells more on the resultant effect of inadequate funding in the university system; part of which has made life uncomfortable for students. That is, when the university is not adequately financed, it leads to the production of substandard services for students, such as lack of infrastructure, electricity, and other social amenities for students, among others. The participant referred to the frustration-aggression theory to substantiate his claim that when students are frustrated, they otherwise become aggressive. Hence, an aggressive man is liable to the forceful request of his or her right. That is, students on campuses commence crises as a result of what is tagged frustration due to extortion, operation, and at times dehumanisation. These challenges seem not to be the sole responsibility of the government as the causes, but other factors include corruption, mismanagement, siphoning and misuse of public funds. This is evidenced below:

SP1: "We cannot ignore the fact that corruption exists within the system. There are so many corrupt administrators who divert funds, mismanage or embezzle money."

SP2: "In fact, it does not only apply to public universities, even students from private universities also protest because of inadequate funds. Therefore, poor funding by the government is a major cause of the crisis."

This is an indication that despite the little and inadequate funds allocated to the university system, the problem of corruption still affects the system. These statements point to the fact that there is mismanagement of public funds, siphoning, and embezzlement. This, to my understanding, will make it impossible for social, educational amenities and materials to be available in the university for students' sustainability. Hence, this is not only peculiar to public or government-owned universities but also spread to private universities. This is evidenced in one of the statements that private university students also protest for proper and adequate funding. Therefore, inadequate, low funding and financing of the university is a challenge to the management of the system, more especially when students decide to go on a rampage to demand good treatment linked to funding.

\subsection{Suggestible Solutions to the Challenges of Managing Students Unrest in Nigerian Universities}

\subsubsection{Provision of Student Personnel Services}

Student personnel services in the university community are considered as important as the university itself because the more available the services are, the more the productivity of the university becomes easy. Not only that but also, it contributes tremendously to the ease in managing the system. This view is supported by Akpan (2016) that student personnel services such as quality healthcare, educational materials, physical facilities like libraries, and its effective management have a direct correlation to the congenial learning environment. Part of these personnel services includes, but not limited to, social amenities such as electricity, water supply, adequate security, affordable, and equitable hostel accommodation for students. Lack of all these resources, according to Onuma and Ada (2016), had led to various students' unrest in Nigeria. Therefore, having them available will reduce student agitation for better life and treatment on campus. These also are reflected in the data generation process. See below:

SP1: "The availability of student personnel services will give the students an insight of the management understanding their plights and are willing to show concern as regards their state of education, well-being and their security level."

The above statement confirms that when all the needed facilities concerning the welfare of students are available, it gives students a sense that the university management is taking cognisance of their needs. Also, it shows that management is leaving no stone unturned in ensuring that the welfare of the members of the university community, most especially students are a priority to university authorities. The social perspective of this is that the availability of these stated amenities by university management will reduce the extent of students' agitation for welfare, quality education, and adequate security. This is also confirmed by Akinnubi and Kayode (2012), that the provision of student welfare services prevents the rate of anti-social behaviours of students on campus. Further conversation 
reveals that the provision of these services is not enough to respond to students' insatiability, but the quality of leaders that are placed to head the personnel services department. This is shown in the conversations below.

SL3 "Student personnel department should be headed by someone that bears the mind of the students and can communicate their needs to the management of the institution without bias."

SL1: "All members involved in the provision and maintenance of students' related facilities should have a listening ear and sensitive to information giving from either of the party."

In the first statement, there is no doubt that the students are always pleased with leaders, teachers, guardians and/or managers who are compassionate to them and their plights. This is to say that anyone that will head such a department should possess humanitarian qualities, who is ready to regard the students as his or her children. By ensuring this, students will have a rest of mind to accept whatever action taken by such an individual (student personnel head). That is, when there is social trust between students and the head of the department, then there will be compromise and understanding to live in harmony. As important as the leader of the students' personnel department is to the plight of the students, so is the maintenance culture of the department. This phase of resource management is important because it is a thing to have those services available, and it is another thing to respond to its maintenance as and when due. Therefore, there must be adequate maintenance of facilities. This, in turn, will prevent in the long run the urge for protest and agitation by students and their leaders. This also responds to one of the assumptions of HRTM: motivation by social, psychological, and economic incentives. That is, social and psychological needs alongside economic incentives motivate subordinates (students) for better productivity.

\subsubsection{Accountability and Transparency}

Transparency and accountability are not just statements when it comes to organisational progress and prosperity. This is because, anywhere or organisations that involve people, where there are leaders, followers, alongside resources, need a sense of openness and trust from the subordinates to be able to see what the leaders are seeing. This is just to say that public office holders, such as university authorities, are responsible for making accountable accounts of their activities such as policies, decisions, and expenditure (Akinbuli, 2013). This accountability is also linked to proper and adequate utilisation of both human and non-human resources available in the university system to achieve the predetermined goals of the system (Akey, 2012). Hence, when all these resources in the system are transparently used with all sense of accountability, this could be tantamount to peaceful coexistence between the authorities and the students, including all other stakeholders. This may be the reason why Fox (2015) stated that accountability in university is synonymous to how conflictual and social contrast between students and university authorities could be ameliorated. This is not only applicable in literature. The reality, as shown in the conversation below, is a call for transparency and accountability as a condition to which peace and tranquillity could be maintained in the university community.

UL2: "Strategies can be put in place to ensure that allotted funds get to the appropriate quarters, and it is well utilised."

UL1: "Students take things to the streets because they are the ones at the receiving end. They pay their tuition fees, but the services they are supposed to be rendered are deprived of them."

UA2: "However, the government should not be blamed because universities should be productive; they should be the peak of knowledge. But most importantly, education should be the primary responsibility of the government."

The above statements show that the practice of accountability and transparency is needed to ensure harmonious relationships among the stakeholders. From the social perspective, when all the resources available in the system are judiciously used, equitably allocated to various departments and units, it is assumed that all needed responsibilities by those departments and units will be done without delay. The second statement also confirms that students engage in protests whenever they feel that the services they are receiving from the university do not correspond with their investments. This makes them believe that university management is extorting and marginalising them. A true and dependable transparent management style would go a long way to rectify the unwanted crisis in the system. However, in many cases, university authorities are not responsible for this perceived unaccountability. This is because, when the universities are short of funds, they tend to make use of all means possible to ensure productivity. This concludes that the issue of accountability and transparency may not be able to be achieved outside the government of the day. The government has its responsibility to perform by ensuring there is adequacy in the financial strength of the university. Therefore, accountability and transparency are some of those factors that bring trust and friendliness in organisations. This, in turn, will reduce the urge for agitation. 


\section{Discussion of Findings}

The findings of the study based on the sub-themes as analysed above were inadequate funding while the suggestible solutions were the provision of student personnel services, and accountability and transparency. This was better represented below;

Table 2. Thematic representation of the findings

\begin{tabular}{lll}
\hline Objectives & \multicolumn{1}{c}{ Findings } \\
\hline $\begin{array}{l}\text { 2. } \\
\text { Challenge associated with the } \\
\text { management of students' unrest in }\end{array}$ & 3. Inadequate Funding. \\
Nigeria universities. & & \\
4. $\begin{array}{l}\text { Suggestible solutions to the challenges of } \\
\text { managing students' unrest in Nigerian } \\
\text { universities. }\end{array}$ & 3. Provision of Student Personnel Services. \\
\hline
\end{tabular}

\subsection{Inadequate Funding}

The findings reveal that the university system in Nigeria is wallowing in the problem of lack of adequate funding. This, according to the literature and analysis, had led to many disagreements and crises between students and university authorities. The analysis also reveals that the little available resources are not judiciously used. There are records of mismanagement, embezzlement and likely siphoning of public funds. This was revealed in the findings made that the university cannot make available all the social amenities and educational facilities for students' sustainability. The issue of underfunding does not only affect public universities but also affect private universities. This aligns with Afe (2014) and Chinyere and Mukoro (2016) that Nigeria is not devoting a reasonable percentage of her annual budget into education. It is also confirmed that Nigeria is still one of the countries that allocate less than $10 \%$ of its annual budget to education (UNESCO, 2002, 2010; Afe, 2014; Premium Times, 2017).

Therefore, inadequate amenities, low funding and mismanagement of funds in universities is a great challenge to the management of the system; more especially when students decide to go on a rampage to demand good treatment linked to funding. The absence of adequate funding is equal to the absence of good infrastructure and other educational facilities in the universities. When all these are absent in schools, agitations, protest and crisis become inevitable. This theoretical perspective speaks to the HRTM assumptions that reiterate the importance of motivation as economic incentives which motivate stakeholders for better productivity (Mayo, 1933). According to Mcgregor (1960), this addresses people's needs and satisfaction that can create a new humanity and builds collective opportunities for all (Cesaire, 1968).

\subsection{Provision of Student Personnel Services and Adequate Maintenance}

The findings here revealed that the availability of student personnel services such as social services and amenities, including educational facilities that will make life easy for students on campuses is essential to ensure peaceful management of the university system. These facilities include, but not limited to health service, pipe-borne water, electricity, adequate classrooms, laboratories, libraries and equipped hostel accommodations. The findings equally reveal that making those facilities available is not enough, but adequate utilisation and maintenance to prevent quick deterioration is necessary. Therefore, it is deduced that the availability of these services and the state of adequate welfare for students by management will reduce the extent of students' agitation for good welfare, quality education and adequate security. This agrees with Akinnubi and Kayode (2012) that the provision of students' welfare services prevents the rate of anti-social behaviours of students on campus. This is also connected to the reason behind the recommendation of motivation by social, psychological and economic incentive as postulated by HRTM. According to the theory, this will positively motivate the subordinates to think ahead of revolts. Therefore, ensuring adequate provision and proper utilisation of student personnel services is a strong condition to consider in managing students oriented crisis in the university system.

\subsection{Accountability and Transparency}

Transparency and accountability as part of the factors needed to solidify harmony in the university community were revealed. The findings further showed that when all the resources available in the system are transparently used with a sense of accountability, they significantly correlated with peaceful relationships. This is because no party will feel cheated or marginalised or underfinanced when all transactions are opened. The discussion further stressed the importance of judicious utilisation and equitable distribution of resources to units across the university as these would increase the sense of trust from subordinates to the super-ordinate. When there is trust, there is less hatred for 
one another. This further confirms the report of GEMR (2017) that accountability is fundamental to how the implicit and conflictual social contrast between students and university authority could be responded to. This aligns with the findings of Fox (2015) that transparency is undoubtedly related to peace and tranquillity. This is also complemented by the finding of Sofoluwe, Oduwaye, Ogundele \& Kayode (2015) that disagreement in tertiary institutions is linked to lack of transparency. From these premises, it becomes logical to conclude that the proper practices of accountability and transparency are a good condition to be taken with all seriousness by the university authorities in managing the system.

\section{Conclusion and Recommendation}

From the findings, it was concluded that the issue of inadequate funding is needed to be addressed because it is found to be the major propeller against the management of students' and authorities' dichotomies. In contrast, the provision of student personnel services and the establishment of accountability and transparency are all predictors of harmonious relationships between university stakeholders, most especially students and university authorities. Based on the findings of the study, it is evidenced that the solutions postulated, such as adequate funding and collaborative governance have worked in some countries, and their peculiarities have also been confirmed empirically to be applicable in Nigeria. Therefore, it becomes expedient in the right direction for university authorities to utilise those approaches to improve the same problems in their universities. Hence, it was deduced that, for a manager to be able to manage stakeholders effectively, provision of student personnel services and the establishment of accountability and transparency must be considered and taken seriously. With these premises, this study, therefore, concludes that adequate funding, provision of student personnel services and the establishment of accountability and transparency are the dimensional elements of peace and tranquillity in the university management system.

\section{References}

Adeyemi, T. O. (2009). Causes, consequences and control of student's crises in public and private universities in Nigeria. Academic Journals of Educational Research and Review, 4(4), 156-163.

Afe, B. (2014). Pathway to sustainable education in Nigeria. Being a text of a keynote address delivered at the 29th conference of the committee of vice-chancellors held at Afe Babalola University (ABUAD) on June 3, 2014.

Ahmad, A. R., Farley, A., \& Naidoo, M. (2018). Funding crisis in higher education institutions: Rationale for change. Asian Economic and Financial Review, 2(4), 562-576.

Akey, L. D. (2012). Institutional accountability and competition for resources in undergraduate Education among US public four-year institutions. Doctoral dissertation, University of Minnesota.

Akinbuli, S. F. (2013). An assessment of accountability in the public sector in Nigeria. Arabian Journal of Business and Management Review, 1(3), 1-11. https://doi.org/10.12816/0003620

Akinnubi, O. P., \& Kayode, D. J. (2012). Student personnel services and students' behaviours in University of Ilorin. Global Journal of Applied Sciences, Management and Social Sciences, 1, 2-14

Akinyemi, B. (2002). Management of students' crisis in higher institutions in Ekiti State. Unpublished M. Ed thesis, University of Ado-Ekiti.

Akpan, C. P. (2016). Student personnel services in higher education. file:///C:/Users/bolab/Downloads/STUDENTPERSONNELSERVICESINHIGHEREDUCATION.pdf. Retrieved 13/02/2020.

Aluede, O. A., Jimoh, B., Agwinede, B. O., \& Omoregie, E. O. (2005). Student unrest in Nigerian universities: Looking back and forward. Journal of Social Science, 10(1), 17-22. https://doi.org/10.1080/09718923.2005.11892454

Aluko, O. E. (2011). The Assessment of housing situation among students in the University of Lagos. African Research Review, 5(3), 104-118. https://doi.org/10.4314/afrrev.v5i3.67345

Analoui, F. (2007). Strategic human resource management. UK: Thomson Learning.

Arikewuyo, M. O. (2015). University management and staff unions in Nigeria: Issues and challenges. SA-eDUC Journal, 3(1), 15-22. https://doi.org/10.5089/9781484307151.002

Barnard, C. I. (1938). The function of an executive. Cambridge: Harvard University Press. 
Bentley, J. M. (2012). Applying dialogic public relations theory to public relations education. Teaching Journalism and Mass Communication, 2(1), 1-11.

Braun, V., \& Clarke, V. (2006). Using thematic analysis in psychology. Qualitative Research in Psychology, 3(2), 77-101. https://doi.org/10.1191/1478088706qp063oa

Braun, V., \& Clarke, V. (2013). Successful qualitative research: A practical guide for beginners. Sage.

Cesaire, A. (1968). Return to my native land. (E. Snyders, Trans.). Paris: Presence Africaine.

Chilisa, B., \& Kawulich, B. (2012). Selecting a research approach: Paradigm, methodology and methods.https://www.researchgate.net/profile/Barbara_Kawulich/publication/257944787_Selecting_a_research _approach_Paradigm_methodology_and_methods/links/56166fc308ae37cfe40910fc/Selecting-a-research-appro ach-Paradigm-methodology-and-methods.pdf/ 09/02/2020.

Chinyere, A., \& Mukoro, S. A. (2016). Policy of carrying capacity and access to university education in Nigeria: Issues, challenges and the way forward. International Journal of Learning, Teaching and Educational Research, 15(9), 55-70.

Davies, K. U., Ekwere, G. E., \& Uyanga, U. U. (2015). Factors influencing students unrest in institutions of higher learning and its implications on the academic performance of students in University of Uyo, Akwa Ibom State, Nigeria. [Online] http://research.rs/wp-content/uploads/2016/06/4-Davies-Ekwere-Uyanga.pdf., retrieved $12 / 02 / 2020$.

Dilshad, R. M., \& Latif, M. I. (2013). Focus group interview as a tool for qualitative research: An analysis. Pakistan Journal of Social Sciences, 33(1), 191-198.

Dube B. (2016). A socio-religious hybridity strategy to respond to the problems of religious studies in Zimbabwe. Ph.D Thesis, Faculty of Education, University of the Free State.

Ekundayo H. T. Alonge H. O. (2010). Managing students' crisis in tertiary institutions in Nigeria. Journal of Research National Development, 8(1), 71-90.

Eldridgea, K., Larryb, L., Bairdc, J., \& Kavanamur, D. (2018). A collaborative governance approach to improving tertiary education in Papua New Guinea. Asia Pacific Journal of Education, 38(1), 78-90. https://doi.org/10.1080/02188791.2018.1423949

Etadon, F. I. (2013). Campus conflict involving students and University Management in Nigeria: A case study of the University of Ibadan. International Journal of Education Science, 5(3), 333-343. https://doi.org/10.1080/09751122.2013.11890094

Etikan, I., \& Bala, K. (2017). Sampling and sampling methods. Biometrics and Biostatistics International Journal, 5(6), 1-3. https://doi.org/10.15406/bbij.2017.05.00149

Fakunle, F. A. (2016). Influence of job satisfaction on job performance among academic staff of tertiary institutions in Ekiti State. M. Ed. Thesis, University of Ado Ekiti, Nigeria.

Falua, B. T. (2004). Management of students crisis in secondary schools in Ado-Ekiti Local Government Area of Ekiti State. M. Ed Thesis, University of Ado Ekiti-, Nigeria.

Famade, O. A., Omiyale, G. T., \& Adebola, Y. A. (2015). Towards improved funding of tertiary institutions in Nigeria. Asian Journal of Humanities and Social Sciences (AJHSS), 3(2), 83-90.

Fox, J. A. (2015). Social accountability: What does the evidence really say? World Development, 72, 346-361. https://doi.org/10.1016/j.worlddev.2015.03.011

FrøLich, N. (2011). Multi-layered accountability. Performance-based funding of universities. Public Administration, 89(3), 840-859. https://doi.org/10.1111/j.1467-9299.2010.01867.x

Gifford, B. (2015). Dr. Oz is no Wizard but No Quack Either. In the New York Times. Retrieved 1/23/2017 from https://www.nytimes.com/2015/04/26/opinion/sunday/dr-oz-is-no-wizard-but-no-quack-either.html

Global Education Monitoring Reports. (2017). Accountability of higher education institutions. http://unesdoc.unesco.org/images/0025/002595/259565e.pdf. 14/10/2019.

Government of Papua New Guinea. (2017). Government committed to promoting the interests of universities. Department of Higher Education, Research, Science and Technology. From 
http://www.dherst.gov.pg/government-committed-in-promoting-the-interest-of-universities/

Retrieved 13/10/2019.

Hamad, A. R., Farley, A., \& Naidoo, M. (2018). Funding crisis in higher education institutions: Rationale for change. Asian Economic and Financial Review, 2(4), 562-576.

Keevash, J., Norman, A., Forrest, H., \& Mortimer, S. (2018). What influences women to stop or continue breastfeeding? A thematic analysis. British Journal of Midwifery, 26(10), https://doi.org/10.12968/bjom.2018.26.10.651

Kitamaya, S., \& Cohen, D. (2010). Handbook of cultural psychology. Guilford Press.

Luthans, F., \& Stajkovic, A. D. (1999). Reinforce for performance: The need to go beyond pay and even rewards. The Academy of Management Executive, 13(2), 49-57. https://doi.org/10.5465/ame.1999.1899548

Maguire, M., \& Delahunt, B. (2017). Doing a thematic analysis: A practical, step-by-step guide for learning and teaching scholars. AISHE-J, 8(3), 3351-3354.

Mayo, E. (1933). The human problem of an industrial civilisation. New York: Macmillan.

McGregor, D. (1960). The human side of enterprise. New York: McGraw-Hill.

Mertens, D. M. (2012). Transformative mixed methods: Addressing inequities. American Behavioral Scientist, 56(6) 802-813. https://doi.org/10.1177/0002764211433797

Mertens, D. M. (2005). Research and evaluation education and psychology: integrating diversity with quantitative, qualitative and mixed methods. London: SAGE publishers.

Nordquist, R. (2019). Conversation Analysis (CA): Glossary of Grammatical and Rhetorical Terms. https://www.thoughtco.com/what-is-conversation-analysis-ca-1689923. 16/02/2020.

Nwanko, J. I. (2014). Management in education: Modern approaches in education management. Ibadan: Giraffe Books.

Odionye C. M. (2014). Evaluation of crisis management strategies in selected universities in south-east Nigeria. M.A Dissertation, University of Nigeria, Nsukka.

Ogunlade, A. L., Ekundayo, H. T., \& Omodan B. I. (2015). Funding and educational facilities as determinants of staff management dichotomy in tertiary institutions in Ekiti State. African Journal of Studies in Education, 10(2), 102-109.

Oludayo, O. A., Uche, O. O. C., Omonijo, D. O., \& Eche, G. A. (2014). Violent protest in private universities in Nigeria: Implications for educational development. European Journal of Social Sciences, 45(4), 359-371.

Omisade, T. (2017). OAU shut indefinitely after protests over an increase in school fees. Daily Post. Available on http://dailypost.ng/2014/06/19/oau-shut-indefinitely-protests-increase-school-fees/ 30/03/208.

Omodan, B. I., Dube, B., \& Tsotetsi, C. T. (2018). Collaborative governance and crisis management in Nigerian universities: An exploration of students' activism. In M. M. Dichaba \& M. A. O. Sotayo (Eds.), Rethinking Teaching and Learning in the $21^{\text {st }}$ Century (pp. 48-68). Pretoria, South Africa: African Academic Research Forum.

Omodan, B. I. (2019). A strategy to enhance crisis management between students and university authorities in Nigeria. PhD thesis, University of the Free State, South Africa.

Omodan, B. I. (2020). Combating the imperativeness of modernity in students' unrest: The need to decolonise the mind through ubuntu. International Journal of Higher Education, 9(4), 310-319. https://doi.org/10.5430/ijhe.v9n4p310

Onuma M., \& Ada N. R. (2016). Evaluation of students' personnel services in colleges of Education in Nigeria. British Journal of Education. 4(7), 82-98.

Onwurah, C. U. (2000). Towards effective management of students' crisis in tertiary institutions. Nigerian Journal of Empirical Studies in Psychology and Education, 1(2), 1-10.

Oraemes, J. C. (1997). Introduction to politics of education. Port Harcourt: Bengray.

Premium Times. (2017). University of Ibadan suspends student union leaders. May 30, 2017. 
Smith \& Rupp. (2003). An examination of emerging strategy and sales performance: Motivation, chaotic change and organisational structure. Marketing Intelligence and Planning, 21(3), 156-167. https://doi.org/10.1108/02634500310474

Sofoluwe, A. O., Oduwaye, R. O., Ogundele M. O., \& Kayode, D. J. (2015). Accountability: A watchword for university administration in Nigeria. The Malaysian Online Journal of Educational Science, 3(3), 1-12.

Stoner, A. F., \& Wandel, C. (1988). Management. (3rd ed.). India: Prentice-Hall.

Undie, J. (2001). Educational governance. Calabar: Tabson.

Watter, J., Momau, S., \& Restall, G. (2010). Participatory action research: An educational tool for citizen users of community mental health services. http://umanitoba.ca/rehabsciences/media/par_manual.pdf/ 11/02/2020.

Weeramunda, A. J. (2008). Socio-political impact of student violence and indiscipline in universities and tertiary education institutes. Research Studies on Tertiary Education Sector. National Education Commission, Sri Lanka.

Wood, L., \& McAteer, M. (2017). Levelling the playing fields in PAR: The intricacies of power, privilege, and participation in a university-community-school partnership. Adult Education Quarterly, 67(4), 251-265. https://doi.org/10.1177/0741713617706541

Wziątek-Staśko, A. (2015). Effective factors in enhancing managers' job motivation cross-cultural context. Management International Conference. Portoroz, Slovenia. 28-30 May 2015.

Zuber-Skerritt, O. (2015). Conceptual framework. In O. Zuber-Skerritt, M. Fletcher, \& J. Kearney (Eds.), Professional learning in higher education and communities: Towards a new vision of action research (1-37). London, England: Palgrave McMillan. https://doi.org/10.1057/9781137455185_1

\section{Copyrights}

Copyright for this article is retained by the author(s), with first publication rights granted to the journal.

This is an open-access article distributed under the terms and conditions of the Creative Commons Attribution license (http://creativecommons.org/licenses/by/4.0/). 